\title{
Analisis Motivasi Belajar Siswa Pada Pembelajaran IPA di SDN16/II Sepunggur
}

\author{
Gusti Nugroho ${ }^{1}$ \\ ${ }^{1}$ SDN 16/II Sepungur, Jambi, Indonesia
}

\begin{tabular}{l} 
Article Info \\
\hline Article history: \\
Received Mei 11, 2020 \\
Revised Mei 20, 2020 \\
Accepted Mei 27, 2020 \\
\hline
\end{tabular}

Keywords:

Motivasi Belajar

Pembelajaran IPA

Pendidikan

Sekolah Dasar

\begin{abstract}
Tujuan penelitian: motivasi belajar siswa erupakan salah satu unsur yang sangat penting. penelitian ini bertujuan untuk menganalisis motivasi belajar siswa di kelas 4 SDN 16/II Sepunggur

Metodologi: Desain penelitian yang digunakan oleh peneliti adalah penelitian kuantitatif yang menggunakan desain penelitian adalah penelitian survey.

Temuan utama: Hasil data pengamatan siswa yang temasuk dalam kategori sangat baik sebesar 20\%, siswa dalam kategori baik sebesar $52 \%$ tau sebanyak 13 siswa, siswa yang termasuk dalam kategori kurang baik sebesar $16 \%$ dan siswa yang termasuk dalam kategori tidak baik sebesar $8 \%$. siswa laki-laki yang termasuk dalam kategori sangat baik sebesar $16,66 \%$, kategori baik sebesar 58,33\%, yang termasuk dalam kategori kurang baik sebesar $16,66 \%$, dan kategori tidak baik sebesar $8,33 \%$. Sedangkan pada siswa perempuan yang termasuk dalam kategori sangat baik sebesar $23 \%$, termasuk dalam kategori baik sebesar $46 \%$, kategori kurang baik sebesar $15,38 \%$ dan yang termasuk dalam kategori tidak baik sebesar 15,38\%.
\end{abstract}

Keterbaruan penelitian: keterbaruan dalam penelitian ini yaitu menganalis sikap motivasi siswa pada pembelajaran IPA yang ada di SDN 16/II Sepunggur.

This is an open access article under the CC BY-NC license

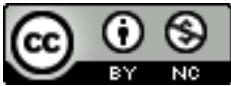

\author{
Corresponding Author: \\ Gusti Nugroho \\ SDN 16/II Sepunggur, Kecamatan Batin II \\ Email: gustinugroho999@gmail.com
}

\section{PENDAHULUAN}

Pendidikan adalah salah satu kunci dalam memajukan suatu bangsa dan negara. [1] Pendidikan yang berhasil akan menciptakan manusia yang pantas dan berkelayakan di masyarakat serta tidak menyusahkan orang lain. Indonesia sesuai dengan konstitusi telah menganggarkan 20\% dari total APBN. Pendidikan sebagai hak asasi setiap individu anak bangsa telah diakui dalam UUD 1945 Pasal 31 ayat (1) yang menyebutkan bahwa setiap warga negara berhak mendapatkan pendidikan. Hal ini menunjukan bahwa pendidikan adalah kunci penting suatu bangsa. [2] Pendidikan memiliki peranan yang sangat penting bagi kemajuan suatu bangsa. Pendidikan sangat penting dalam membentuk karakter diri seorang manusia. [3] Manusia menjadi baik atau buruknya adalah akibat faktor pendidikan dan lingkungan, bukan kepada tabiat aslinya. Manusia pada dasrnya adalah makhluk yang terus tumbuh dan berkembang baik fisik maupun mentalnya. [4] Perkembangan dapat diartikan sebagai proses perubahan kuantitatif dan kualitatif individu dalam rentang kehidupnnya, mulai dari masa konsepsi, masa bayi, masa kanak-kanak, masa remaja, sampai masa dewasa. Proses pendidikan yang dialami oleh manusia dalam proses perkembangnya sangat 
berpengaruh pada perkembang itu sendiri. [5] Science and technology has led to a process of change in all aspects of life, including the world of education.

Pendidikan yang lakukan dapat membentuk dan mengembangan segala potensi diri yang dimiliki setiap insan. [6] Adanya proses belajar, menyebabkan manusia senantiasa dapat mengembangkan dirinya serta mengatualisasikan segala kemampuan yang dimilikinya. Pendidikan secara sederhana adalah proses pembelajaran yang dilakukan disekolah. [7] Tugas dan peranan guru sebagai pendidik profesional sesungguhnya sangat kompleks, tidak terbatas pada saat berlangsungnya interaksi edukatif di dalam kelas, yang lazim disebut proses belajar mengaja. Keberhasilan pembelajaran tersebut sangat bergantung pada diri setiap siswa. Salah satunya adalah pembelajaran IPA disekolah dasar.

Pembelajaran IPA merupakan salah satu pembelajaran yang terpadu dengan pembelajaran lainya. Pembelajaran IPA disekolah dasar berkenaan dengan konsep ilmiah alam sekitar. [8] Pembelajaran Ilmu PengetahuanAlam (IPA) berkaitan dengan cara mencari tahu tentang alam secara sistematis. [9] Pembelajaran IPA tidak bisa dengan cara menghafal atau pasif mendengarkan guru menjelaskan konsep namun siswa sendiri yang harus melakukan pembelajaran melalui percobaan, pengamatan maupun bereksperimen. Guru harus mampu memfasilitasi siswa untuk paham tentang alam sekitar. Pembelajaran IPA diharapkan mampu untuk menjadi salah satu langkah agar siswa mampu mamahami alam sekitar dengan baik. [10] Sebagai pengembangan pola pikir peserta didik maka mata pelajaran yang terkait adalah Ilmu Pengetahuan Alam (IPA). Nilai-nilai dalam pembelajaran IPA diharapkan dapat diterapkan dalam kehidupan siswa. [11] Pembelajaran IPA diharapkan bisa menjadi wahana bagi siswa untuk mempelajari diri sendiri dan alam sekitar, serta pengembangan lebih lanjut dalam penerapan dalam kehidupan sehari-hari. Keberhasilan siswa dalam pembelajaran IPA disekolah juga dapat dipengaruhi oleh bagaimana motivasi belajar siswa sendiri.

Motivasi belajar siswa merupakan salah satu hal yang sangat penting. motivasi adalah keadaan dimana seorang siswa memiliki kemauan dan semangat yang tinggi terhadap pembelajaran. Amni 999 Motivasi merupakan dorongan seseorang secara sadar atau tidak sadar untuk melakukan sesuatu kegiatan untuk mencapai tujuannya. Ada nya motivasi yang tinggi dapat mendorong terciptanya hasil belajar yang baik. [13] Apabila seorang memiliki motivasi dan kebiasaan yang baik maka setiap usaha yang dilakukan akan memberikan hasil yang memuaskan. Hasil belajar yang baik menunjukan siswa telah mencapai tujuan belajar dan prestasi belajar. [14] Hasil analisis menunjukkan bahwa motivasi belajar berpengaruh positif dan signifikan terhadap prestasi belajar. Motivasi belajar akan memberi damapak kepada keberhasilan siswa. [15] Motivasi akan memberi dampak pada hasil belajar siswa, baik secara langsung ataupun tidak langsung. [16] Peserta didik yang memiliki motivasi belajar yang tinggi terhadap pembelajaran maka mereka akan tergerak atau tergugah untuk memiliki keinginan melakukan sesuatu yang dapat memperoleh hasil atau tujuan tertentu. Meningkatkan motivasi siswa menjadi tantangan besar bagi seorang guru. Guru yang mampu meingkatkan motivasi belajar siswa dapat dikatakn sebagai guru yang profesional. Sepunggur?

Berdasarkan hal tersebut peneliti akan menanalisis bagaimana motivasi belajar siswa di SDN. 16/II

\section{METODE PENELITIAN}

Desain penelitian yang digunakan oleh peneliti adalah penelitian kuantitatif yang menggunakan desain penelitian adalah penelitian survei. [17] Survey research is a procedure in quantitative research where researchers administer surveys to a sample or to the entire population used to describe population attitudes, opinions, behaviors, or special characteristics. Sampel dalam penelitian ini diperoleh dari 25 siswa SDN 16/II Sepunggur dengan menggunakan teknik purvosive sampling. Penelitian ini menggunakan instrumen pengamatan, kuesioner dan wawancara. Kuesioner memiliki 12 pernyataan valid dengan nilai reliabilitas 0,72 dan menggunakan wawancara terstruktur yang bertujuan memperkuat data kuantitatif.

\section{HASIL DAN PEMBAHASAN}

Motivasi belajar siswa sangat menentukan bagaimana siswa dapat mengikuti pembelajaran dengan baik. Motivasi belajar siswa juga sangat berkaitan dengan cara guru melaksanakan pembelajaran didalam kelas. Selain itu, motivasi siswa dapat dilihat berdasarkan sikap siswa pada saat proses pembelajaran berlangsung. Berikut hasil pengamatan sikap motivasi siswa dikelas pada saat pembelajaran IPA dilaksanakan:

Tabel 1. Hasil Pengamatan Motivasi Siswa 


\begin{tabular}{cccc}
\hline No & Kategori & Frekuensi & $\%$ \\
\hline 1 & Sangat Baik & 5 & 20 \\
2 & Baik & 13 & 52 \\
3 & Kurang Baik & 4 & 16 \\
4 & Tidak Baik & 2 & 8 \\
\hline & total & 25 & 100
\end{tabular}

Berdasarkan hasil pengamatan yang dilakukan, siswa yang temasuk dalam kategori sangat baik sebesar 20\%, siswa dalam kategori baik sebesar 52\% tau sebanyak 13 siswa, siswa yang termasuk dalam kategori kurang baik sebesar $16 \%$ dan siswa yang termasuk dalam kategori tidak baik sebesar $8 \%$.

Siswa yang termasuk kategori sangat baik terlihat sangat aktif dlam proses pembelajaran. Siswa hadir sebelum jam pembelajaran dilaksanakan. Saat pembebelajaran dilaksanakan siswa terlihat memiliki semangat yang sangat tinggi, rajin dalam bertanya, memperhatian guru saat proses pembelajaran dan sangat komunikatif. Siswa mampu mengerjakan tugas yang diberikan guru secara mandiri dan penuh tanggung jawab. Sementara siswa yang temasuk dalam kategori baik juga melaksanakan pembelajaran dengan penuh semangat. Siswa juga terlihat aktif dalam bertanya namu terkadang masih tidak memperhatikan guru. Sedang siswa yang termasuk dalam kategori yang kurang baik dan tidak baik yaitu siswa terlihat kurang bersemangat dalam proses pembelajaran. Siswa sering bermain dan ribut saat pembelajaran dilaksanakan. Siswa juga terkadang sering keluar kelas. Tindakan tersebut menunjukan bahwa siswa memiliki motivasi belajar yang masih kurang. siswa yang memiliki motivasi belajar yang tinggi mencerminkan tindakan dan sikap seperti pada kategori sangat baik dan baik. [18] Ciri-ciri siswa yang memiliki motivasi belajar yang baik seperti berikut: Tekun, Ulet, mennjukan minat terhadap macam-macam masalah, bekerja secara mandiri, senang berpendapat, teguh dalam keyakinan, dan senang memecahkan masalah. Motivasi belajar menjadi unsur yang sangat penting dalam pembelajaran. [19] Dalam proses belajar, motivasi sangat diperlukan, sebab seseorang yang tidak mempunyai motivasi dalam belajar, tidak akan mungkin melaksanakan aktivitas belajar.

Selanjutnya siswa diberikan angket tentang motivasi belajar, berikut hasil angket untuk mengukur motivasi belajar siswa:

Tabel 2. Hasil angket motivasi belajar siswa

\begin{tabular}{|c|c|c|c|c|c|c|c|}
\hline & \multicolumn{3}{|c|}{ Laki-laki } & & \multicolumn{3}{|c|}{ Perempuan } \\
\hline & Kategori & Frekuensi & $\%$ & & Kategori & frekuensi & $\%$ \\
\hline Siswa & Sangat baik & 2 & 16,66 & \multirow{4}{*}{$\begin{array}{c}\text { Siswa kelas } 4 \\
\text { SDN 16/II } \\
\text { Sepunggur }\end{array}$} & Sangat baik & 3 & 23 \\
\hline kelas 4 & Baik & 7 & 58,33 & & Baik & 6 & 46 \\
\hline SDN 16/II & Kurang baik & 2 & 16,66 & & Kurang baik & 2 & 15,38 \\
\hline Sepunggur & tidak baik & 1 & 8,33 & & tidak baik & 2 & 15,38 \\
\hline \multicolumn{2}{|c|}{ Total } & 12 & 100 & \multicolumn{2}{|c|}{ Total } & 13 & 100 \\
\hline
\end{tabular}

Berdasarkan tabel 2 tersebut, siswa laki-laki yang termasuk dalam kategori sangat baik sebesar $16,66 \%$, kategori baik sebesar 58,33\%, yang termasuk dalam kategori kurang baik sebesar 16,66\%, dan kategori tidak baik sebesar $8,33 \%$. Sedangkan pada siswa perempuan yang termasuk dalam kategori sangat baik sebesar $23 \%$, termasuk dalam kategori baik sebesar $46 \%$, kategori kurang baik sebesar 15,38\% dan yang termasuk dalam kategori tidak baik sebesar $15,38 \%$.

Hasil analisis data angket tersebut menunjukan bahwa terdapat kecenderungan bahwa siswa telah memiliki motivasi belajar yang baik. [20] indikator motivasi belajar adalah sebagaimana berikut ini : a. Minat dan perhatian siswa terhadap pelajaran b. Semangat siswa untuk melakukan tugas-tugas belajarnya $c$. Tanggung jawab dalam mengerjakan tugas-tugas belajarnya d. Reaksi yang ditunjukkan siswa terhadap stimulus yang diberikan oleh guru e. Rasa senang dan puas dalam mengerjakan tugas yang diberikan. Berdasarkan hasl analisis angket,siswa yang termasuk dalam kategori baik dan sangat baik memiliki minat dan perhatian belajar yang tinggi. Siswa memperhatikan pada saat guru menjelaskan pembelajaran. Siswa juga memiliki semangat dalam belajar, penuh tanggung jawab dalam mengerjakan tugas dari guru dan tdak mudah bosan saat pelajaran sedang berlangsung. Sementara siswa dengan kategori yang kurang baik dan tidak baik memiliki semangat belajar yang rendah saat proses pembelajaran. Siswa sering ribut sendiri dan kurang fokus terhadap pembelajaran. 
Guru sebagai fasilitator pada saat pembelajaran harus secara aktif dan kreatif dalam meningkatkan motivasi belajar siswa. [21] Guru harus dapat merancang proses pembelajaran dan menyajikan materi secara kreatif dan inovatif. Banyak langkah yang dapat digunakan guru dalam meningkatkan motivasi belajar siswa. Salah satunya dengan menggunakan media pembelajaran yang menarik. Media pembelajaran yang menarik dapat menarik perhatian siswa sehingga dapat meningkatkan motivasi belajar siswa. [22] Penerapan media pembelajaran sebagai sumber belajar diharapkan dapat meningkatkan pemahaman siswa yang diiringi peningkatan prestasi belajar. Selain itu guru juga dapat menggunakan metode pembelajaran yang beragam dengan tujuan memuat pembelajaran tidak menjadi membosankan. [23] A professionally trained teacher can use different methods of teaching successfully. It is really a very difficult task and only a professionally qualified teacher can do this.

Sementara dari hasil wawancara yang dilakukan didapatkan hasil sebagai berikut :

1. Siswa yang memiliki motivasi belajar tinggi meyikini bahwa dengan bersemangat saat belajar mereka akan mampu mendapatkan nilai yang bagus.

2. Mereka beranggapan bahwa orang tua mereka selalu menyemangati mereka agar serius dalam belajar disekolah.

3. Mereka semakin semangat belajar ketika guru mereka memberikan hadiah ataupaun mengajak mereka untuk praktek.

4. Beberapa dari siswa mengatakan bahwa IPA adalah pembelajaran yang sangat menyenangkan dan mengasikkan karena dekat dengan alam.

5. Sementara siswa yang lain mengatakan bahwa mereka memiliki motivasi belajar yang baik karena mereka juga suka terhadap mata pelajaran IPA.

6. Selain itu siswa juga mengatakan bahwa guru yang baik dan ramah membuat mereka menyukai pembelajaran dikelas.

7. Sedang siswa dengan motivasi belajar rendah mengatakan bahwa IPA adalah pembelajaran yang sulit.

8. Selain itu mereka juga mengatakan bahwa mereka kurang menyukai pembelajaran IPA.

Berdasarkan hasil wawancara tersebut dapat diartikan bahwa tinggi rendahnya motivasi setiap siswa dipengaruhi berbagai faktor. Yaitu faktor instrinsik dan ekstrinsik. [24, 25] faktor yang berasal dari dalam diri pelajar (faktor internal) yang meliputi: kemampuan intelektual, afeksi seperti perasaan dan percaya diri, motivasi, kematangan untuk belajar, usia, jenis kelamin, kebiasaan belajar, kemampuan mengingat, dan kemampuan penginderaan seperti melihat, mendengarkan, dan merasakan. Faktor dari dalam misalnya semangat yang selalu diberikan orang tua. Sedangkan faktor dari luar misalnya lingkungan belajar dan pengaruh dari teman sejawat.

\section{KESIMPULAN}

Berdasarkan hasil penelitian tersebut, motivasi belajar siswa merupakan salah satu faktor penting dalam menunjang keberhasilan belajar dan tercapainya tujuan pembelajaran. Siswa yang memiliki motivasi belajar yang baik akan bersemangat pada saat proses pembelajaran dilaksanakan. Motivasi belajar di SDN 16/VIII Sepunggur telah memiliki kecenderungan baik. Hasil data pengamatan siswa yang temasuk dalam kategori sangat baik sebesar 20\%, siswa dalam kategori baik sebesar 52\% tau sebanyak 13 siswa, siswa yang termasuk dalam kategori kurang baik sebesar $16 \%$ dan siswa yang termasuk dalam kategori tidak baik sebesar $8 \%$. siswa laki-laki yang termasuk dalam kategori sangat baik sebesar 16,66\%, kategori baik sebesar $58,33 \%$, yang termasuk dalam kategori kurang baik sebesar 16,66\%, dan kategori tidak baik sebesar 8,33\%. Sedangkan pada siswa perempuan yang termasuk dalam kategori sangat baik sebesar $23 \%$, termasuk dalam kategori baik sebesar $46 \%$, kategori kurang baik sebesar $15,38 \%$ dan yang termasuk dalam kategori tidak baik sebesar $15,38 \%$.

Ada dua faktor yang mempengaruhi motivasi belajar siswa yaitu instrinsik dan ekstrinsik. Faktor ini menjadi tantangan bagi guru dalam melaksanakan pembelajaran. Guru haru sekreatif dan inovatif mungkin sehingga siswa menjadi tertarik dalam proses pembelajaran.

\section{UCAPAN TERIMA KASIH}

Peneliti mengucapkan terimaksih kepada kepala sekolah SDN 16/II Sepunggur, siswa dan siswi serta para dewan guru SDN 16/II Sidorejo yang telah memberikan dukungan kepada peneliti sehingga peneliti mampu menyelesaikan penelitian ini. 


\section{REFERENSI}

[1] Suprihatin, S. Upaya Guru Dalam Meningkatkan Motivasi Belajar Siswa. Jurnal Pendidikan Ekonomi. Vol. 3. No. 1. Pp. 73-82. 2015

[2] Lussianda, E, O. Analisis Dimensi Yang Membentuk Motivasi Siswa Dalam Belajar. Jurnal Curricula. Vol. 1, No. 3. Pp. 1-10. 2016.

[3] Mualamin. Konsep Fitrah Manusia dan Implikasinya Dalam Pendidikan Islam. Jurnal Tarbiyyah : Jurnal Pendidikan Islam. Vol. 8, No. II. Pp.249-265. 2017.

[4] Latifa, U . Aspek Perkembangan pada Anak Sekolah Dasar: Masalah dan Perkembangannya. Academia Journal of Multidiciplinary studies, Vol. 1, No.2. 2017.

[5] Syahrial, S., Asrial, A., Kurniawan, D. A., Nugroho, P., Septiasari, R., Pratama, R. A., \& Perdana, R. . Increased Behavior of Students' Attitudes to Cultural Values Using the Inquiry Learning Model Assisted by Ethnoconstructivism. Journal of Educational Science and Technology (EST), vol. 5, No.2, 166. 2019. https://doi.org/10.26858/est.v5i2.9670.

[6] Haryono, S. Pengaruh Kedisiplinan Siswa Dan Motivasi Belajar Terhadap Prestasi Belajar Siswa Pada Mata Pelajaran Ekonomi. Faktor Jurnal Ilmiah Kependidikan, 3(3). Pp. 261-274. 2016.

[7] Julia, P \& Ati. (2019). Peranan Guru Dalam Meningkatkan Nilai Karakter Disiplin Dan Kejujuran Siswa. Jurnal Dedikasi Pendidikan 3(2).112-122

[8] Kurniasih, D. Peningkatan Minat Dan Hasil Belajar Ipa Melalui Model Pembelajaran Think Pair Share. Natural: Jurnal Ilmiah Pendiidkan IPA. Vol. 5 No.1. pp 7-11 2018.

[9] Sulthon. Pembelajaran Ipa Yang Efektif Dan Menyenangkan Bagi Siswa Madrasah Ibtidaiyah (Mi). Jurnal ELEMENTARY. Vol. 4, No. 1. Pp 38-54. 2016.

[10] Astalini, Kurniawan, D, A., Putri, A, D., Identifikasi Sikap Implikasi Sosial Dari Ipa, Ketertarikan Menambah Waktu Belajar Ipa, Dan Ketertarikan Berkarir Dibidang Ipa Siswa Smp Se-Kabupaten Muaro Jambi. Jurnal Tarbiyah: Jurnal Ilmiah Kependidikan. Vol. 7 No. 2. Pp. 93-108. 2018.

[11] Surahman, Paudi, R, I \& Tureni, D., Meningkatkan Hasil Belajar Siswa Dalam Pembelajaran IPA Pokok Bahasan Makhluk Hidup Dan Proses Kehidupan Melalui Media Gambar Kontekstual Pada Siswa Kelas II SD Alkhairaat Towera. Jurnal Kreatif Tadulako Online. Vol. 3 No. 4. Pp 91-107. 2014

[12] Fauziah, A, Rosnaningsih, A \& Azhar, S. Hubungan Antara Motivasi Belajar Dengan Minat Belajar Siswa Kelas Iv Sdn Poris Gaga 05 Kota Tangerang. Jurnal JPSD. Vol. 4. No. 1. Pp.47-53. 2017.

[13] Damis \& Mujahis. Analisis Hubungan Antara Motivasi Belajar Dengan Hasil Belajar Siswa Pada Sekolah Dasar Negeri 3 Allakuang Kecamatan Maritengngae Kabupaten Sidenreng Rappang. Jurnal IDAARAH. Vol. 2. No. 2. Pp. 216-228. 2018.

[14] Suranto. Pengaruh Motivasi, Suasana Lingkungan Dan Sarana Prasarana Belajar Terhadap Prestasi Belajar Siswa (Studi Kasus Pada Sma Khusus Putri Sma Islam Diponegoro Surakarta.Jurnal Pendidikan Ilmu Sosial. Vol. 25, No. 2. Pp 11-19. 2015.

[15] Saptono, Y, J. Motivasi dan Keberhasilan Belajar Siswa.Jurnal Pendidikan Agama Kristen REGULA FIDEI. Vol. 1. No. 1. 2016.

[16] Emda, A. Kedudukan Motivasi Belajar Siswa Dalam Pembelajaran. Lantanida Journal. Vol. 5, No. 2. Pp. 93-196. 2017.

[17] Creswell, J. W. Educational Research: Planning, Conducting and Evaluating Quantitative and Qualitative Research (4th ed.). Boston: Edwards Brothers, Inc. 2012

[18] Emda, A. Kedudukan Motivasi Belajar Siswa Dalam Pembelajaran. Lantanida Journal. Vol. 5, No. 2. Pp. 93-196. 2017.

[19] Manuhutu, S. Analisis Motivasi Belajar Internal Siswa Program Akselerasi Kelas Viii Smp Negeri 6 Ambon. Jurnal Pendidikan Ekonomi UM Metro. Vol. 3. No. 1. 2015.

[20] Sudjana, 2009. Prestasi kerja Dalam Prestasi kerja Organisasi Modern. Penerbit Erlangga, Jakarta.

[21] Sari, I. Motivasi Belajar Mahasiswa Program Studi Manajemen Dalam Penguasaan Keterampilan Berbicara (Speaking) Bahasa Inggris. Jurnal Manajemen Tolls. Vol. 9. No. 2018

[22] Kurniasih, D. Peningkatan Minat Dan Hasil Belajar Ipa Melalui Model Pembelajaran Think Pair Share. Natural: Jurnal Ilmiah Pendiidkan IPA. Vol. 5 No.1. pp 7-11. 2018.

[23] Muhammad, A, Problems Of Prospective Teachers During Teaching Practice', Academic Research International, vol. 1, Issue 2. 2011.

[24] Pebruanti, L. Peningkatan Motivasi Hasil Belajar Pada Mata Pelajaran Pemograman Dasar menggunakan Modul Di SMKN 2 Sumbawa. Jurnal Pendidikan Vokasi. Vol. 5. No. 3Pp. 365-376. 2015.

[25] Yuliana, I. Pembelajaran Berbasis Etnosains Dalam Mewujudkan Pendidikan Karakter Siswa Sekolah Dasar. Jurnal Pendidikan Dasar dan Pembelajaran Sekolah Dasar. Vol. 1No. 2. 2017. 